\title{
ANALISIS KEMAMPUAN PENALARAN MATEMATIS SISWA KELAS IV SDN GAYAMSARI O2 DI KOTA SEMARANG
}

\author{
Ahmad Subqi Arianto', Joko Sulianto ${ }^{2}$, Mira Azizah ${ }^{3}$ \\ Fakultas Ilmu Pendidikan, Universitas PGRI Semarang \\ email: upgrisubqi@gmail.com
}

\begin{abstract}
The objectives of this study are: (1) Describe the implementation of mathematics learning at Gayamsari 02 Semarang Elementary School (2) Describe the classification of mathematical reasoning abilities of fourth grade students at Gayamsari Elementary School 02 Even Semester 2018/2019. The method used in this study is a qualitative method. Research location at Gayamsari 02 Elementary School Semarang. Data collection is done through observation, questionnaires, interviews and documentation as well as for collecting data on mathematical reasoning abilities of students using test questions. The validity of the data is done by means of triangulation techniques. Based on the data analysis that has been done, mathematics learning is included in the good category with an average score above 3, mathematical reasoning classification data obtained the highest results of $56.41 \%$ and the lowest results of $10.25 \%$, it can be concluded that the implementation of mathematics learning at SDN Gayamsari 02 Semarang shows good results, but for the results of tests on mathematical reasoning questions related to students' ability to reason with material in many aspects and flat build is still lacking,
\end{abstract}

Keywords: mathematical reasoning, problem solving, elementary school mathematics

\section{Abstrak}

Tujuan penelitian ini adalah: (1) Mendeskripsikan implementasi pembelajaran matematika di SDN Gayamsari 02 Semarang (2) Mendeskripsikan klasifikasi kemampuan penalaran matematis siswa kelas IV SDN Gayamsari 02 Semester Genap 2018/2019. Metode yang digunakan pada penelitian ini adalah metode kualitatif. Lokasi penelitian di SDN Gayamsari 02 Semarang. Pengumpulan data dilakukan melalui observasi, angket, wawancara dan dokumentasi serta untuk pengumpulan data kemampuan penalaran matematis siswa menggunakan soal tes. Keabsahan data dilakukan dengan cara triangulasi teknik. Berdasarkan analisis data yang telah dilakukan, pembelajaran matematika termasuk dalam kategori baik dengan rata-rata skor diatas 3, data klasifikasi penalaran matematis didapatkan hasil tertinggi sebesar 56,41\% dan hasil terendah sebesar 10,25\%, bisa disimpulkan bahwa pelaksanaan pembelajaran matematika di SDN Gayamsari 02 Semarang menunjukkan hasil yang baik, namun untuk hasil tes pada soal penalaran matematis terkait kemampuan siswa dalam bernalar dengan materi segi banyak dan bangun datar masih kurang.

Kata kunci: penalaran matematis, pemecahan masalah, matematika Sekolah Dasar 


\section{PENDAHULUAN}

Bernalar merupakan salah satu aspek penting dalam kegiatan belajar.

Pada kegiatan bernalar terdapat sebuah proses yang sistematis serta esensial. Proses bernalar tersebut bisa kita temukan juga pada pembelajaran matematika. Matematika memerlukan suatu cara sistematis untuk merangsang serta menumbuhkan pola pikir sebagai prosedur pemecahan suatu masalah atau persoalan tertentu. Proses sistematis tersebut akan membantu pembentukan sebuah dorongan yang berupa satu kapasitas untuk melakukan sesuatu yaitu sebuah kemampuan, dalam hal ini adalah kemampuan dalam proses bernalar yang berkaitan dengan matematika. Kemampuan tersebut adalah kemampuan matematis. Ada beberapa kemampuan yang merupakan suatu kemampuan matematis, baik itu kemampuan dalam hal isi atau konten materi ataupun dalam hal proses matematis, salah satu kemampuan matematis yang didasarkan pada proses matematis adalah kemampuan penalaran.
Penalaran sendiri merupakan suatu proses berpikir yang mengharuskan seseorang untuk dapat menarik suatu simpulan dari sebuah pernyataan yang kebenarannya telah dibuktikan sebelumnya. Thorndike dalam Schunk (2012: 74) yang diterjemahkan dari buku Learning Theories yang menyatakan bahwa setiap orang terlibat pada berbagai pembelajaran yang melibatkan ide menghubungkan, menganalisis, serta penalaran.

Peraturan Menteri No. 21 Tahun 2016 tentang Standar Isi menyebutkan bahwa proses pendidikan dimaksudkan untuk membentuk kompetensi dengan substansi tujuan pendidikan nasional dalam aspek sikap spiritual dan sikap sosial, pengetahuan, serta keterampilan. Masing-masing aspek memiliki proses pemerolehan yang berbeda. Pada aspek keterampilan khususnya, Keterampilan dapat diperoleh melalui aktivitas-aktivitas: mengamati, menanya, mencoba, menalar, menyaji, dan mencipta. Ditetapkannya proses menalar dalam kompetensi keterampilan, itu berarti 
bahwa penalaran menjadi salah satu aspek penting untuk dilibatkan dalam suatu pembelajaran yang tentunya harus dimiliki oleh siswa. Secara konseptual, kemampuan berpikir atau bernalar matematis telah tersurat dalam rangkaian kompetensi pembelajaran yang dituangkan dalam Permendikbud RI Nomor 37 Tahun 2018 tentang Kompetensi Inti dan Kompetensi Dasar Satuan Pendidikan Dasar dan Menengah. Khususnya pada pembelajaran matematika, dimensi berpikir atau bernalar matematis tertuang dalam rangkaian kompetensi pembelajaran yang tersusun menjadi satu kecakapan khusus yang harus dikuasai siswa terutama pada jenjang pendidikan dasar.

Fajri (2017: 6) menyatakan bahwa penalaran matematis merupakan salah satu indikasi dari bentuk pengembangan kemampuan berpikir matematis khususnya pada proses pembelajaran matematika. Ruseffendi ET dalam Suherman (Tim MKPBM , 2001:18) juga menyatakan bahwa matematika terbentuk sebagai hasil pemikiran manusia yang berhubungan dengan ide, proses dan penalaran. Penalaran tersebut berupa pengembangan kemampuan untuk memecahkan masalah, serta mengembangkan kemampuan menyampaikan informasi atau mengkomunikasikan ide gagasan. Selaras dengan hal tersebut Subanindro (2012) dalam penelitiannya menyatakan kemampuan penalaran matematis adalah kemampuan untuk menghubungkan antara ide-ide atau objek-objek matematika, membuat, menyelidiki dan mengevaluasi dugaan matematik, dan mengembangkan argumen-argumen dan bukti-bukti matematika untuk meyakinkan diri sendiri dan orang lain bahwa dugaan yang dikemukakan adalah benar. Dapat disimpulkan bahwa penalaran matematis merupakan suatu bentuk proses berpikir untuk dapat menarik kesimpulan dari suatu pernyataanpernyataan tertentu, yang apabila dilatih serta dikembangkan dengan baik akan memudahkan dalam mengkomunikasikan matematis baik secara tertulis maupun lisan.

Penalaran menjadi salah satu aspek penting dalam belajar 
matematika. Kemampuan penalaran matematis dapat membantu siswa untuk memberikan sebuah kesimpulan, mengembangkan dan membangun suatu ide gagasan, serta memecahkan masalah pada matematika, sehingga nantinya siswa akan lebih terampil serta tidak lagi mengalami kesulitan mengerjakan persoalan yang ada. Hasil penelitian yang dilakukan oleh Permana (2007) juga mengatakan bahwa kemampuan penalaran matematis siswa yang memperoleh pembelajaran berbasis masalah lebih baik dari pada penalaran matematis siswa melalui pembelajaran biasa, karena melalui penalaran matematis tersebut, siswa akan mampu memecahkan persoalan tertentu yang dihadapinya. Pembelajaran yang menyertakan permasalahan atau persoalan matematika di dalamnya menjadi salah satu upaya penting sebagai perangsang munculnya pola pikir untuk menemukan prosedur pemecahan suatu permasalahan tertentu, dari permasalahan atau persoalan tersebut nantinya akan diarahkan pada penarikan suatu kesimpulan, sehingga kemampuan penalaran matematis siswa dapat terasah serta terbiasa melakukan proses bernalar yang lebih baik. Selain itu pemecahan masalah sendiri merupakan bagian dari proses bernalar matematis, sehingga hal tersebut bisa lebih memperkuat bahwa pembelajaran matematika dengan memanfaatkan proses penalaran sangat diperlukan.

Berdasar penjelasan di atas, pembelajaran matematika dalam pelaksanaannya ternyata tidak sepenuhnya diaplikasikan seperti itu, permasalahan umum yang terjadi adalah masih rendahnya kemampuan penalaran matematis itu sendiri. Guru yang seringkali masih menggunakan pola belajar yang biasa atau konvensional dalam pengajaran matematika di beberapa materi tertentu, dan siswa tidak dilatih untuk menggunakan penalaran yang logis dalam menyelesaikan soal-soal matematika yang umumnya lebih bersifat kontekstual. Hidayati (2013: 1) dalam penelitiannya menyatakan bahwa rendahnya kemampuan penalaran matematika diduga 


\section{Jurnal Sinektik}

Volume 2 Nomor 2, Edisi Desember 2019

Prodi PGSD Universitas Slamet Riyadi

ISSN 2620-6560 (print) ISSN 2620-746X (online)

disebabkan oleh penekanan

konvensional.

Meningkatnya

pembelajaran di kelas yang masih

kemampuan penalaran siswa

menekankan pada keterampilan

disebabkan dalam pembelajaran

mengerjakan soal (drill), sehingga

selalu mengaitkan materi dengan

kurang memberikan kesempatan

pengalaman siswa, sehingga siswa

kepada siswa untuk membangun

sendiri pengetahuan yang mereka

miliki. Hal ini mengakibatkan siswa

kurang terbiasa mengerjakan soal-

soal pemecahan masalah yang

menuntut mereka untuk bernalar.

Materi hanya mengikuti serangkaian

prosedur dan meniru contoh-contoh tanpa mengetahui maknanya.

Diperkuat lagi dengan guru yang seringkali masih mengabaikan dengan tidak memberikan siswa sebuah persoalan yang melibatkan proses penalaran dalam proses pembelajarannya. Penggunaan pola belajar konvensional sistem drill, tidak membuat siswa aktif bernalar. Dibuktikan dengan hasil penelitian oleh Fuadi, Rahmi, Rahmah Johar dan Said Munzir (2016) bahwa ratarata peningkatan kemampuan Penalaran matematis siswa yang mendapat pembelajaran dengan pendekatan kontekstual lebih tinggi dibandingkan dengan siswa yang mendapat pembelajaran berkesan dibandingkan dengan pembelajaran dimana diperoleh bergantung pada informasi dari guru.

Merujuk pada permasalahan tersebut, peneliti melakukan wawancara di SD N Gayamsari 02, dengan narasumber Ibu Nita Wulaningrum yang juga mengampu sebagai guru kelas di kelas IV. Berdasarkan wawancara tersebut diperoleh informasi bahwa pembelajaran matematika yang diajarkan untuk siswa adalah menyesuaikan dengan materinya, bisa kontekstual yang melibatkan proses bernalar atau konvensional yang sekedar memberi contoh dan menghafal suatu rumus. Informasi lain dari narasumber menyatakan bahwa $75 \%$ siswa kelas IV masuk dalam kriteria baik. Dibuktikan juga dengan lembar data hasil belajar penilaian harian yang diberikan narasumber kepada peneliti. Dari informasi yang diberikan narasumber 
serta data hasil belajar, bisa diartikan $25 \%$ siswa masih kurang, tetapi $75 \%$ lainnya sudah cakap bermatematika. Bisa dikatakan dari $75 \%$ siswa memiliki peluang untuk belajar bernalar matematis dengan baik.

Seperti yang dijelaskan di atas, kaitannya dengan bernalar matematika sudah diperkenalkan dan diajarkan pada pendidikan jenjang sekolah dasar. Karena di sekolah dasar, siswa telah belajar matematika. Mulai dari mengenal angka, berhitung, pengenalan rumus, sampai dengan pemahaman konsep tertentu dalam matematika. Matematika merupakan salah satu mata pelajaran yang membutuhkan proses bernalar dalam kajian dan aspek tertentu, terutama siswa kelas tinggi yang seharusnya telah matang dan mampu diajak untuk berpikir logis untuk menentukan metode atau konsep tertentu yang menjadi salah satu indikator dari penalaran matematis.

Pentingnya penalaran matematis dikuatkan dengan penelitian yang dilakukan oleh Kusumawardani, Dyah Retno, Wardono dan Kartono (2018: 589) yang menyatakan bahwa Penalaran memiliki peran penting dalam matematika karena dijadikan sebagai pondasi bagi standar proses lainnya. Selain itu, penalaran dan matematika tidak dapat dipisahkan satu sama lain karena dalam menyelesaikan permasalahan matematika memerlukan penalaran sedangkan kemampuan penalaran dapat dilatih dengan belajar matematika.

Berdasar konteks penelitian tersebut, peneliti melakukan penelitian dengan judul "Analisis Kemampuan Penalaran Matematis Siswa Kelas IV SDN Gayamsari 02 Semester Genap 2018/2019 Di Kota Semarang"

Berdasarkan konteks penelitian tersebut maka dapat diambil fokus penelitian yaitu (1) Implementasi pembelajaran matematika di SDN Gayamsari $02 \quad$ Semarang

Klasifikasi kemampuan penalaran matematis siswa kelas IV SDN Gayamsari 02 Semester Genap 2018/1019. 


\section{METODE PENELITIAN}

Penelitian ini menggunakan metode kualitatif deskriptif dengan tujuan untuk untuk mendeskripsikan bagaimana pembelajaran matematika, serta menganalisis kemampuan penalaran matematis siswa kelas IV SDN Gayamsari 02 Semarang.

Subjek penelitian ini adalah guru dan siswa kelas IV SDN Gayamsari 02 Semarang. Kedua subjek juga menjadi sumber data bagi peneliti untuk mengetahui bagaimana implementasi pembelajaran matematika serta untuk mengetahui klasifikasi penalaran matematis siswa kelas IV.

Teknik pengumpulan data pada penelitian ini dilakukan dengan triangulasi teknik yaitu melalui observasi, wawancara serta kuesioner. Observasi, wawancara serta kuesioner digunakan untuk mengetahui kondisi lapangan serta untuk mengetahui bagaimana pelaksanaan pembelajaran matematika di kelas IV SDN Gayamsari 02 Semarang. Untuk melihat serta menganalisis kemampuan penalaran matematis siswa, digunakan instrumen tes yang berupa soal penalaran matematis. selain itu digunakan juga dokumentasi untuk memperkuat bukti pada saat pelaksanaan pengumpulan data.

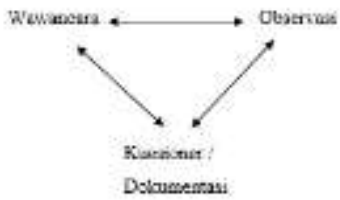

Gambar 1. Triangulasi teknik dengan tiga pengumpulan data

\section{HASIL DAN PEMBAHASAN}

1. Implementasi pembelajaran matematika

Untuk mengetahui bagaimana pembelajaran matematika di SDN Gayamsari 02 Semarang digunakan lembar kuesioner. Data yang didapatkan merupakan data hasil kuesioner dengan tiga aspek yaitu: aspek pembelajaran, aspek pendekatan saintifik, aspek penalaran. Ketiga aspek tersebut dirangkum dalam satu proses pembelajaran sehingga didapatkan hasil data berikut: 
Tabel 1. Data Hasil Kuesioner

\begin{tabular}{ccccc}
\hline No & Aspek & Skor & Rata-rata & Kategori \\
\hline 1 & Aspek Pembelajaran & 120 & 3,52 & Baik \\
\hline 2 & Aspek Pendekatan Saintifik & 36 & 3,6 & Baik \\
\hline 3 & Aspek Penalaran Siswa & 54 & 3,37 & Baik \\
\hline
\end{tabular}

Kategori Penilaian:

Skor 4: Sangat baik

Skor 3: Baik

Secara keseluruhan dari tinjauan ketiga aspek yang terdapat pada kuesioner tersebut semuanya menyatakan baik dengan skor ratarata diatas 3. Bisa diartikan bahwa proses pembelajaran matematika di SDN Gayamsari 02 Semarang terlaksana dengan baik.

Data kuesioner tersebut diperoleh melalui dua responden yang berbeda yaitu responden pertama dari guru kelas I dan responden kedua dari guru kelas IV. Berdasarkan data pada tabel 1 di atas, total skor yang diperoleh dari aspek pembelajaran sebesar 120. Yang mana skor tersebut didapat dari hasil gabungan kedua responden. Responden pertama yaitu guru kelas I dengan skor sebesar 61 dan responden kedua yaitu guru kelas IV mendapatkan skor sebesar 59.
Skor 2: Kurang baik

Skor 1: Tidak baik

Sehingga skor rata-rata menunjukkan angka 3,52 dengan kategori baik. Pada aspek pendekatan saintifik, diperoleh dari responden pertama yaitu guru kelas I sebesar 17 dan pada responden kedua yaitu guru kelas IV sebesar 19. Sehingga total skor yang dihasilkan adalah 36 dengan rata-rata skor keduanya pada aspek tersebut sebanyak 3,6 yang menunjukkan kategori baik pula. Pada aspek ketiga yaitu aspek penalaran siswa diperoleh rata-rata skor sebesar 3,37. Rata-rata skor tersebut juga diperoleh melalui gabungan dua responden dengan hasil yang diapat pada responded pertama yaitu guru kelas I sebesar 26 dan pada responden kedua yaitu guru kelas IV sebesar 28. Sehingga dihasilkan skor rata-rata yang mampu menunjukkan kategori baik. 
Selain dari kuesioner tersebut, untuk mengetahui bagaimana proses pembelajaran matematika juga dilakukan wawancara terhadap guru dan siswa, berdasarkan wawancara tersebut beberapa siswa mengatakan matematika adalah mata pelajaran yang susah untuk beberapa materi tertentu. Terkait dengan pembelajaran di kelas, siswa mengatakan pembelajaran yang dilakukan adalah dengan penyampaian materi kemudian dilanjut dengan pemberian soal. Selain itu siswa juga mengatakan pada materi tertentu digunakan media LCD sebagai penyampaiannya. Disana siswa merasa lebih paham terhadap materi. Sedangkan wawancara yang dilakukan oleh guru kelas IV mendapatkan hasil bahwa pembelajaran yang dilakukan di kelas memang benar untuk mempermudah pemahaman siswa terkait materi yang sedang diajarkan adalah menggunakan sebuah media yang dalam hal ini adalah penggunaan LCD proyektor yang berisikan sebuah video relevan dengan materi yang diajarkan. Selain itu siswa juga diberikan kebebasan untuk mengeksplor pembelajaran secara lebih nyata atau konkrit. Misal dalam hal perkalian, pembagian serta hitungan lainnya yang secara tidak langsung tersirat pada saat kita berbelanja di sebuah supermarket misalnya. Tujuan guru menerapkan hal tersebut adalah untuk lebih memahamkan siswa bahwa matematika bukan sekedar ilmu yang dipelajari dalam buku, melainkan matematika mampu melekat dan sering dijumpai pada kehidupan sehari-hari. Pembelajaran matematika di kelas IV SDN Gayamsari 02 Semarang lebih memfokuskan pembelajaran yang lebih kontekstual, nyata dan konkrit.

2. Klasifikasi kemampuan penalaran matematis

Hasil data pada penelitian ini adalah untuk mengukur kemampuan bernalar matematis siswa berdasarkan sepuluh aspek penalaran yaitu (1) memahami contoh negatif, memahami pengertian, (3) membuat alasan, (4) menarik kesimpulan, (5) menentukan strategi, (6) berpikir logis, (7) berpikir sistematis, (8) berpikir kosisten, (9) berpikir deduksi, dan (10) menentukan 
Volume 2 Nomor 2, Edisi Desember 2019

Prodi PGSD Universitas Slamet Riyadi

ISSN 2620-6560 (print) ISSN 2620-746X (online)

metode. Pada temuan penelitian berikut:

didapatkan hasil penelitian sebagai

Tabel 2. Data Hasil Penelitian Aspek Penalaran Matematis Siswa

\begin{tabular}{llcc}
\hline $\begin{array}{c}\text { No. } \\
\text { Soal }\end{array}$ & Aspek Penalaran & $\begin{array}{c}\text { Persentase } \\
\text { Jawaban } \\
\text { Benar }\end{array}$ & $\begin{array}{c}\text { Skor } \\
\text { rata- } \\
\text { rata }\end{array}$ \\
\hline 1 & Memahami contoh negatif & $17,94 \%$ & 1,79 \\
\hline 2 & Memahami pengertian & $15,38 \%$ & 2,94 \\
\hline 3 & Membuat alasan & $35,89 \%$ & 6,79 \\
\hline 4 & Menarik kesimpulan & $46,15 \%$ & 12,15 \\
\hline 5 & Menentukan strategi & $53,84 \%$ & 7,61 \\
\hline 6 & Berpikir logis & $53,84 \%$ & 7,71 \\
\hline 7 & Berpikir sistematis & $51,28 \%$ & 6,69 \\
\hline 8 & Berpikir konsisten & $10,25 \%$ & 6,17 \\
\hline 9 & Berpikir deduksi & $10,25 \%$ & 4,12 \\
\hline 10 & Menentukan metode & $56,41 \%$ & 6,79 \\
\hline & & & \\
\hline
\end{tabular}

Persentase hasil hitung tepat atau soal yang tidak dijawab didapatkan melalui perhitungan oleh siswa. Sedangkan untuk jawaban benar pada masing-masing mendapatkan hasil hitung rata-rata nomor soal dengan beracuan pada skor diperoleh dengan menghitung skor maksimal, selain itu juga dengan rata-rata skor disetiap nomor atau memperhatikan hasil pekerjaan siswa, aspek penalaran dibagi dengan baik itu dari jawaban yang kurang banyaknya siswa uji coba.

Tabel 3. Rincian dan Rekap Jawaban Siswa

\begin{tabular}{lccc}
\hline $\begin{array}{l}\text { No. } \\
\text { soal }\end{array}$ & Jawaban benar & $\begin{array}{c}\text { Jawaban } \\
\text { kurang tepat }\end{array}$ & $\begin{array}{c}\text { Tidak menjawab } \\
\text { soal }\end{array}$ \\
\hline 1 & 7 & 32 & - \\
\hline 2 & 6 & 33 & - \\
\hline 3 & 14 & 25 & - \\
\hline 4 & 18 & 21 & - \\
\hline 5 & 21 & 18 & - \\
\hline 6 & 21 & 17 & 1 \\
\hline 7 & 20 & 18 & 1 \\
\hline 8 & 4 & 34 & 3 \\
\hline 9 & 4 & 32 & 4 \\
\hline 10 & 22 & 13 &
\end{tabular}


Pada soal nomor (1) didapatkan jawaban benar sebanyak 7 siswa dengan artian hanya $17,94 \%$ siswa yang mahir dalam bernalar memahami contoh negatif. Pada soal nomor (2) didapatkan jawaban benar sebanyak 6 siswa dengan artian hanya $15,38 \%$ siswa yang mahir dalam bernalar memahami pengertian. Pada soal nomor (3) didapatkan jawaban benar sebanyak 14 siswa dengan artian hanya $35,89 \%$ siswa yang mahir dalam bernalar membuat alasan. Pada soal nomor (4) didapatkan jawaban benar sebanyak 18 siswa dengan artian hanya 46,15 $\%$ siswa yang mahir dalam bernalar menarik kesimpulan. Pada soal nomor (5) didapatkan jawaban benar sebanyak 21 siswa dengan artian hanya 53,84 \%siswa yang mahir dalam bernalar menentukan strategi. Pada soal nomor (6) didapatkan jawaban benar sebanyak 21 siswa dengan artian hanya 53,84\% siswa yang mahir dalam bernalar berpikir logis. Pada soal nomor (7) didapatkan jawaban benar sebanyak 20 siswa dengan artian hanya 51,28\% siswa yang mahir dalam bernalar berpikir sistematis. Pada soal nomor (8) didapatkan jawaban benar sebanyak 4 siswa dengan artian hanya 10,25\% siswa yang mahir dalam bernalar berpikir konsisten. Pada soal nomor (9) didapatkan jawaban benar sebanyak 4 siswa dengan artian hanya $10,25 \%$ siswa yang mahir dalam bernalar berpikir deduksi. Pada soal nomor (10) didapatkan jawaban benar sebanyak 22 siswa dengan artian hanya 56,41 \% siswa yang mahir dalam bernalar menentukan metode.

Secara keseluruhan dari data tersebut bisa dikatakan penalaran matematis siswa masih terbilang rendah. Selain itu didominasi oleh jawaban siswa yang menunjukkan tidak lebih dari separuh siswa yang menjawab dengan benar pada masingmasing soal. Persentase tertinggi didapat sebesar $56,41 \%$ dan terendah sebesar $10,25 \%$.

Bentuk soal pada setiap aspek penalaran dapat dilihat pada gambar berikut: 
Jurnal Sinektik

Volume 2 Nomor 2, Edisi Desember 2019

Prodi PGSD Universitas Slamet Riyadi

ISSN 2620-6560 (print) ISSN 2620-746X (online)

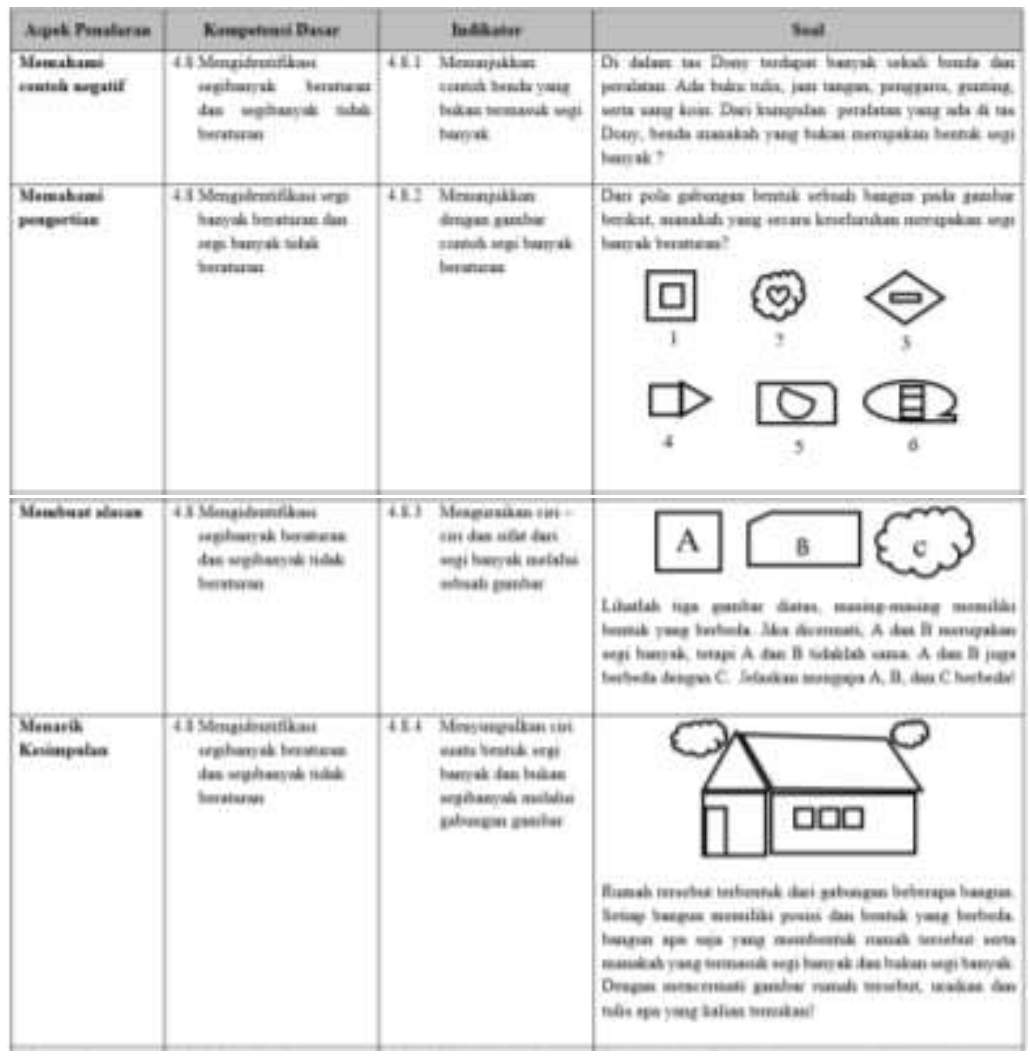

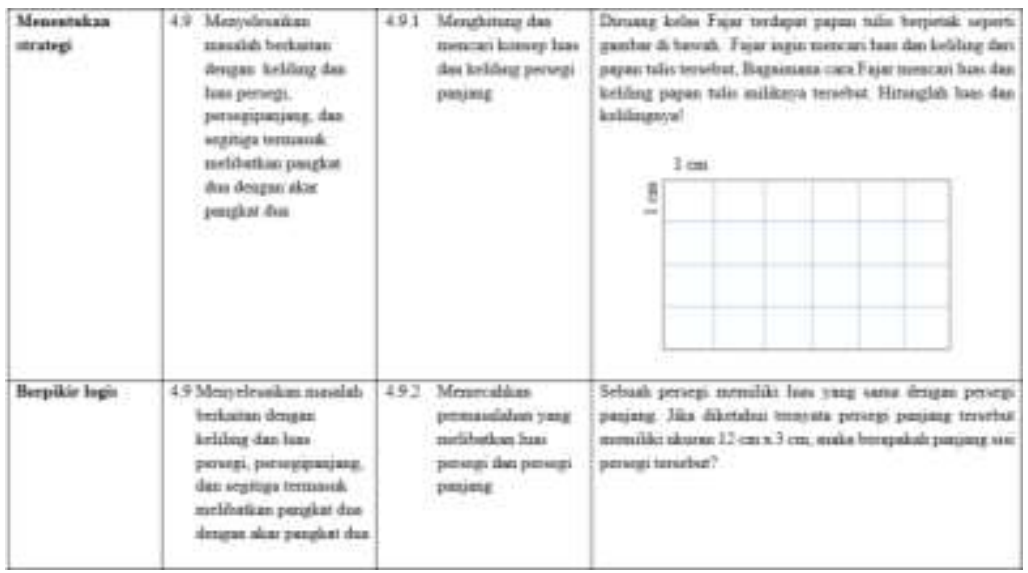

\begin{tabular}{|c|c|c|c|c|}
\hline $\begin{array}{l}\text { Herpalir } \\
\text { diensati }\end{array}$ & 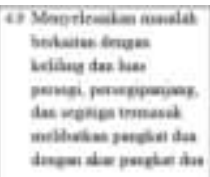 & 162 & 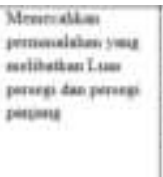 & 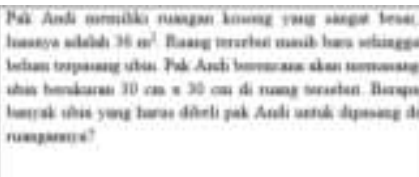 \\
\hline Berpalir kabuites & 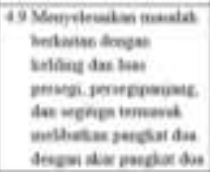 & .63 & 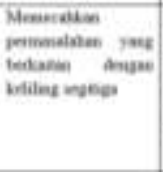 & 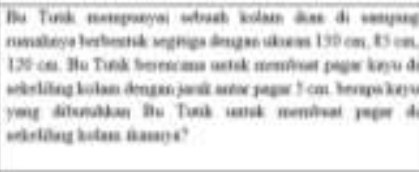 \\
\hline
\end{tabular}




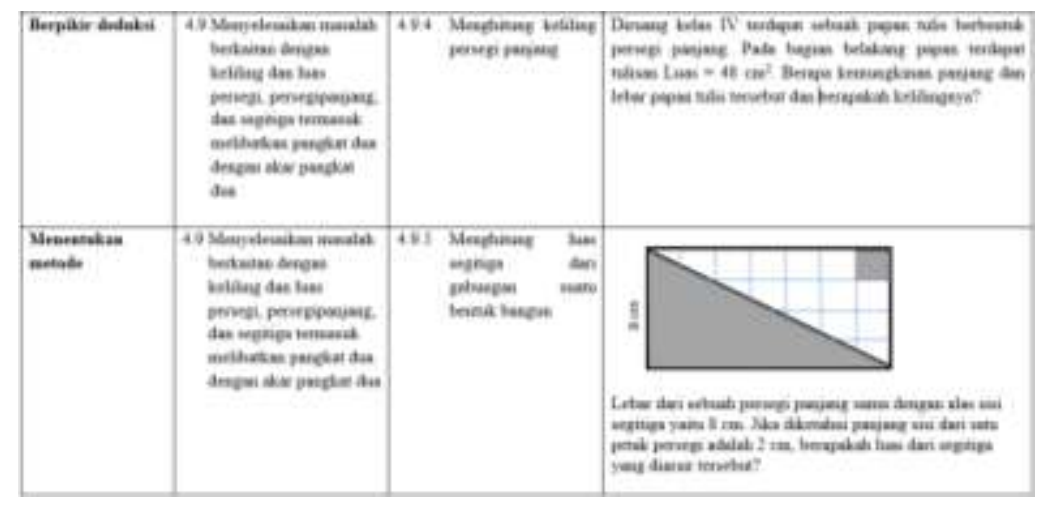

Gambar 2. Bentuk Soal Berdasar Aspek Penalaran

\section{SIMPULAN}

Berdasarkan hasil penelitian

dan hasil pembahasan yang telah diuraikan, maka terlihat bahwa implementasi pembelajaran matematika serta kemampuan penalaran matematis siswa kelas IV SDN Gayamsari 02 Semarang ditinjau dari aspek penalaran serta pemecahan masalah sudah baik. Pada pembelajaran matematika di kelas oleh guru kelas IV lebih menerapkan pola belajar konkrit dan nyata untuk menambah pemahaman siswa terhadap materi tertentu yang relevan dengan apa yang dilakukan dalam kehidupan sehari-hari. Namun untuk pemahaman siswa terhadap soal penalaran dengan materi segi banyak dan bangun datar masih harus diperhatikan, diperlukan adanya tindak lanjut, dikarenakan hasil yang menunjukkan masih rendahnya proses bernalar siswa di beberapa aspek penalaran matematis.

Berdasarkan hasil penelitian yang telah diperoleh, maka saran yang dapat diberikan adalah sebagai berikut:

1. Bagi siswa diharapkan mampu menjadikan penelitian ini sebagai motivasi dalam mengembangkan kemampuan bernalar matematis serta memahami berbagai karakteristik persoalan matematis.

2. Bagi guru diharapkan lebih memperhatikan kemampuan penalaran matematis siswa selama proses pembelajaran.

3. Bagi peneliti berikutnya diharapkan dapat lebih berinovasi dengan mengembangkan model penelitian yang lebih menarik serta 
Jurnal Sinektik

Volume 2 Nomor 2, Edisi Desember 2019

Prodi PGSD Universitas Slamet Riyadi

ISSN 2620-6560 (print) ISSN 2620-746X (online)

dengan hasil yang bernilai

informatif.

\section{DAFTAR PUSTAKA}

Tim MKPBM. 2001. Strategi Pembelajaran Matematika

Kontemporer. Bandung: JICA

Kusumawardani, Dyah Retno, Wardono dan Kartono. 2018. Pentingnya Penalaran Matematika dalam Meningkatkan Kemampuan Literasi Matematika. PRISMA, Prosiding Seminar Nasional Matematika, (1):588-595

Schunk, Dale.H. 2012. Learning Theories: An Educational Perspectives, 6th Edition. New York: Pearson Education Inc.

Fajri, Muhammad. 2017. Kemampuan Berpikir Matematis dalam Konteks Pembelajaran Abad 21 di Sekolah Dasar. Jurnal Lemma.Vol.3.No.2.

Hidayati, Kusuma Nur. 2013. Peningkatan Kemampuan Penalaran Matematika Siswa Melalui Model Pembelajaran Learning Cycle "5-E" Dengan Menggunakan Alat Peraga Pada Siswa Kelas V SD N 03 Mudal Boyolali Tahun Ajaran 2012/2013. Jurnal Publikasi:UMS

Subanindro. 2012. Pengembangan Perangkat Pembelajaran Trigonometri Berorientasikan Kemampuan Penalaran Dan
Komunikasi Matematika. (https://eprints.uny.ac.id/1009 9/, diakses 14 April 2019)

Permana, Yanto. dkk. 2007. Mengembangkan Kemampuan Penalaran dan Koneksi Matematik Siswa SMA Melalui Pembelajaran Berbasis Masalah. Jurnal. Vol.1,No.2:UPI.

Fuadi, Rahmi, Rahmah Johar dan Said Munzir. 2016 Peningkatkan Kemampuan Pemahaman dan Penalaran Matematis melalui Pendekatan Kontekstual. Jurnal Didaktika Matematika. Vol.3.No.1

Depdiknas. 2016. Peraturan Menteri Pendidikan Nasional Nomor 21, Tahun 2016, tentang Standar Isi Pendidikan Dasar dan Menengah. Jakarta: Depdiknas.

Depdiknas. 2016. Peraturan Menteri Pendidikan Nasional Nomor 37, Tahun 2018, tentang Kompetensi Inti Dan Kompetensi Dasar Pelajaran Pada Kurikulum 2013 Pada Pendidikan Dasar dan Pendidikan Menengah. Jakarta: Depdiknas. 